\title{
To Improve the Quality of Ideological and Political Education of College Students in the Perspective of "Supply-Side Structural Reform"
}

\author{
Wang Rui \\ Student Development and Affairs Center of Bohai University, 121000 Jinzhou, Liaoning, China
}

Keywords: supply-side structural reform, ideological and political education of college students, quality promotion

\begin{abstract}
Supply-side structural reform" theory has not only promoted healthy and sustainable development for economy but also provided a totally new perspective to guide the implementation and development of ideological and political education in universities. Using "Supply-side structural reform" theory to examine ideological and political education in universities has great referential value to strengthen and improve the quality of ideological and political education of students and to realize effective balance between "supply-side" and "demand-side" of ideological and political education.

As economy, politics, education has been closely related with the whole modern social life, "supply-side reform" in economics is bound to lead to education reform. "Supply-side" and "demand-side" are both unify and opposite just like two sides of a coin. They have influences on each other at the same time, supply create demand and vice versa. "Supply-side structural reform" is both a reform method and a thinking path. Nowadays, under a complex economic situation at home and abroad, it is necessary to develop and cultivate "new energy" and transform and upgrade "old energy" from both supply side and demand side to improve the development concept under the new situation and promote the structural reform. The ideological and political education in colleges and universities also has a certain degree of imbalance between "supply side" and "demand side", leading to stagnation of "new energy" and "old energy" has no opportunity to be upgraded.
\end{abstract}

\section{The importance of "supply-side structural reform"}

\subsection{Macro-demands of national economic and social development.}

At present, China has entered a new normal stage, a kind of national situation in a new period. Xi Jinping pointed out "Understand new normal, adapt new normal, lead new normal is a grand logic of our national economic development now and in future “[1]. The new normal is the base for China to enter a new and higher platform after decades of economic development. Therefore, only through the supply-side structural reform in the new normal, can economic development gain new power to realize steady economic growth. Xi Jinping put forward a concept "strengthen supply-side structural reform” in the eleventh meeting of the Leading Group for Financial and Economic Affairs on $10^{\text {th }}$ November 2015. "The nature of supply-side structural reform is a reform, and it is necessary to use the reform approach to promote the structural adjustment, so as stimulate endogenous power and create an external environment for quality improvement. Supply-side reform has become a hot topic even in the education field since the central government raised the policy of strengthening supply-side structural reform.

\subsection{The regional demand of economic and social development in Liaoning}

President Xi Jinping pointed out that supply-side structural reform is the only road to prosper Liaoning when participated the fifth session of the twelfth National People's Congress and examine the Liaoning delegation. During the $13^{\text {th }}$ five-year plan, Liaoning should firmly carry forward supply-side structural reform, promote the liberation of old industrial bases and develop social 
productive forces, enlarge effective and mid-to-high end supply, enhance the adaption and flexibility of supply structure to demand changes, improve the total factor productivity, put forward the realization of the prosperity of old industrial bases ${ }^{[2]}$ through reducing capacity, inventory, lever, cost and repairing short slab follow a series of significant indication about prosperity development by president Xi Jinping. The revitalization of Liaoning is inseparable from the cultivation of talents and the innovation of science and technology. We should be problem-oriented, and put eyes on the supply of industries and the society, commit to the supply-side structural reform of higher education, enhance talents cultivation, promote scientific innovation, enhance the "new energy" of social development, and enhance the connotation construction of colleges and universities in service revitalization.

\subsection{The objective demand of the demand-side reform of service object}

Education is to cultivate people, and make education environment, allocate education resources, offer people cultivation are all supply-side problems. Now we face a problem that education structure is not reasonable. Generally, our education has many shortcomings and insufficient, such as lack of high-quality education resources, simplex education resources, not fit with industrial development, etc. Traditional talent cultivation mode can't meet the needs of society, leading to personnel training come part from the market, students lack the spirit of innovation, restricting the quality of education. The lack of effective supply leads to the intensification of education demand, which makes the need of supply side structural reform more prominent. The ideological and political education, as a part of the education field, also faces the urgency of deepening the supply-side structural reform. On the one hand, improve the quality of ideological and political education and increase the innovation and efficiency to make ideological and political education normal and daily and close to the needs and habits of students. It should meet the individual development of students as well as meet the needs of society. On the other hand, the ideological and political education supply structure is rich and diversified, which makes education resources, environment and service diversified, as well as meets demands of the demand side.

\section{Supply-side structural adjustment is an urgent affair of ideological and political education in current colleges and universities.}

\subsection{Neglecting the subjectivity of the supply side makes the productivity of ideological and political education surplus.}

At present, the ideological and political education of colleges and universities is obsolete and monotonous with single educational methods, which is seriously out of line with the social reality and lack of pertinence and effectiveness. There are many theories of ideology and politics while few social practices. In other words, it focuses on theory rather than cultivating abilities. Educators still teach in old manners, education methods can't match with the time, which neglects objectivity of demand side and the demand and individuality of students, leading bad education performance and surplus ideological and political education.

\subsection{Neglecting the influence of the supply side leads bad performance of ideological and political education}

Ideological and political education for students of colleges and universities should pay attention to the demand side as well as strengthen the cultivation and improvement of self-ability in supply side. At present, colleges and universities attach importance to ideological and political education of students, but it mainly depends on teachers of ideological and political education and full-time instructors. Current education strength is not enough to meet the demand of ideological and political education. As teachers of professional courses are busy with their professionals and scientific research and administrators are busy with administrative affairs, ideological and political education still depends on instructors, so it's difficult to form an "ideological and political" environment that departments and professional teachers pay attention to, and to form join forces for ideological and 
political work. Therefore, the self-anility and awareness of supply side should be improved to effectively balance supply side and demand side and avoid imbalance in two sides.

\section{The methods to improve ideological and political education for college and university students in the perspective of "supply-side structural reform".}

\subsection{Increase supply entity to enhance the core strength of ideological and political education.}

The supply entity of ideological and political education should realize synergic governance of multiplicity and enhance the core strength of ideological and political education. We should bring professional teachers, administrative staffs into the system of ideological and political education, combine social and family forces, use effective social resources such as excellent schoolfellows, noted public figures and entrepreneurs while build the instructors team a main layout with multielements to form a main multiple layout joined by family, school, education entities. In addition, the degree of students' participation should be improved. The concept that students represent both demand and supply of ideological and political education. Fully give play to the leading role of advanced students, respect the subject consciousness of students, mobilize their sense of participation, form a model of self-management, self-education and self-service, in which students take part in affairs and administration democratically.

\subsection{Optimize supply contents to improve the inner driven force of ideological and political education.}

The content of ideological and political education should be optimized and enlarged, and the quality of ideological and political education in the "supply side" should be promoted. Ideological and political education in colleges and universities is a huge and complicated systematic engineering, which includes ideological and moral education, mental health education, legal education, etc. These contents rely on and influence each other. The supply contents of ideological and political education must combine the theoretical height with the social reality closely in order to realize the effective supply of ideological and political education. In addition, the current investment in various types of ideological and political education resources, resulting in a large number of education "products". However, repeated inputs that separate from students actually lead to inventory backlog. Therefore, we should adjust the supply structure, firmly grasp the current gap and short boards of ideological and political education, create ideological and political education boutique to achieve cutting overcapacity and inventory and improving the quality of ideological and political education.

\subsection{Adjust supply methods and enhance the guarantee of ideological and political education.}

Ideological and political education need to adjust its supply model, divide levels and categories, so that ideological theories can combine and unify with social practice. As students in colleges and universities are multiple, and postgraduate, graduate and junior college students are different groups, they face different problems. Therefore, ideological and political education models for different groups of students should be established to realize vertical and precise supply for ideological and political education. Furthermore, we should also pay attention to the ideological and political education teaching methods, the diversification of the methods, the vivid teaching activities, and the interaction in educational practice. Change the traditional teaching methods, carry out the exchange of interactive teaching mode, construct practical teaching base, bring employment, innovation and entrepreneurship, social practice and volunteer service into play, realize the combination of teaching and practice, enhance the educational experience, provide students with diversified and alternative educational service model, realize horizontal and accurate supply of ideological and political education, so as to effectively improve the quality of ideological and political education.

\subsection{Construct supply environment and create outer elements for ideological and political education.}

Ideological and political education need to build supply environment, pay attention to the 
construction of campus culture, attach importance on the outer elements of ideological and political education. Strengthen natural conditions and infrastructure construction of campus, beautify physical environment of campus, reflect education entity and humanistic care and strengthen appearance factors in ideological and political education. We should excavate recessive factors in ideological and political education and take advantage of them such as school spirit, school history and school rules except those to further build cultural environment such as school culture, academic atmosphere, school network. Using persistence to realize the infiltration of education environment.

In short, the ideological and political education of the "supply-side structural reform" is not simply deny the demand side, nor is it blindly to meet the needs of students, but to reflect the traditional ideological and political education, to fasten the transformation of ideological and political education methods, to break deep contradictions in the development of ideological and political education. This practice of reflection provides ideological and political education innovation with new perspectives as well as expands upside potential for the quality of ideological and political education.

\section{Acknowledgement}

This article is a phasic research result of the Liaoning social and scientific planning fund project "A Research on the Improvement of the Quality of Ideological and Political Education for College Students” in 2016 (Project Number: L16DSZ002).

\section{References}

[1] The Central Economic Working Conference in Beijing [N]. People’s Daily,2015-12-22(1).

[2] Zhang Wanqiang. Supply-side structural reform is the only path to make Liaoning prosperous[EB/OL]. http://liaoning.nen.com.cn/system/2017/03/16/019728023.shtml,2017-03-16.

[3] Yang Xiaomin, Du Yuhong, Gao Bing. Strategies for education development and suggestions for the 13th five-year plan [J]. China Education Journal, 2016(3).

[4] Zhao Xue. A research on discourse innovation of ideological and political education of college students in the we-media era [J]. The Journal of Changchun Normal University,2017(1).

[5] Jin Xiaocan, Ma Yingzhe. Innovative research on ideological and political education of college students under the background of supply-side reform [J]. Higher Education Journal,2017(3). 